\title{
THINK-PAIR-SHARE: ENGAGING STUDENTS IN SPEAKING ACTIVITIES IN CLASSROOM
}

\author{
Dian Aprianti' ${ }^{1}$, Mutiara Ayu ${ }^{2}$ \\ Universitas Teknokrat Indonesia ${ }^{1,2}$ \\ dianapriyanti144@gmail.com ${ }^{1}$, mutiara.ayu@teknokrat.ac.id ${ }^{2}$
}

\begin{tabular}{lll}
\hline Received: 8 May 2020 & Accepted: 12 June 2020 & Published: 27 June 2020 \\
\hline
\end{tabular}

\begin{abstract}
Think-Pair-Share technique is one of the cooperative learning strategies that promote student involvement in the classroom. This strategy makes students engaged in in-class activities such as discussions and provides opportunities to share their ideas with others. The purpose of this study was to describe the implementation of the Think-Pair-Share strategy in teaching speaking skill for secondary students. A qualitative method with a descriptive analysis was undertaken in this study. The sample was twenty students of eighth grade. The data was collected through interviews, observation, and document analysis. The data analysis technique used was presented in a descriptive form. The results indicated the implementation of the Think-Pair-Share technique during the learning process took place following the stages that have been stated in the learning process plan made by the teacher. Appreciation for the implementation of the Think-Pair-Share technique both from students is quite good. Students stated that they can overcome the constraints in the learning process of speaking activity through ThinkPair-Share.
\end{abstract}

Keywords: Think-Pair-Share, cooperative learning, engaging, speaking

\section{To cite this article:}

Aprianti, D. \& Ayu, M. (2020). Think-Pair-Share: Engaging Students Activities in Classroom. Journal of English Language Teaching and Learning, 1(1), 13-19.

\section{INTRODUCTION}

One form of education that is implemented in schools and family environments from an early age is language education because language is a very important tool in life. People can interact with each other by sharing and receiving messages or information (Sari, 2018). Besides, people can express thoughts and feelings towards others, develop expressions, and at the same time develop intellectual abilities through language.

Language education at school is an effort to achieve language skills according to its function, which is a function as a means of communication, thinking, and reasoning. To fulfill the communication function, language learning at school aims to improve language skills. According to Nunan (2003), language skills include four components, namely listening skill, speaking skill, reading skill, and writing skill. The four language skills can be grouped into two, namely the ability to understand (receptive) and use (production). Receptive skill consists of two language skills, namely listening (Kuswoyo and Wahyudin, 2017) and reading skills. Productive skill consists of speaking and writing skills. Speaking skill is the earliest language productive skill able to be controlled by someone. Before being able to write, people first produce language orally. Even illiterates have the speaking ability. Therefore, speaking skill is a very important language skill.

Unfortunately, the fact is that some students thought that speaking skill is one of the most avoided skills in English. The reality in the field shows that from year to year, students' learning outcomes in speaking English are below the completeness criteria. The objective of learning speaking skills is that students can communicate in English fluently. According to Raba (2017), the low learning outcomes of speaking English can be caused by various factors, namely, internal factors and external factors. Internal factors are factors originating from the students themselves which include low intrinsic motivation of students to speak English, self-confidence, background knowledge of students, and learning strategies. There is a relationship between learning strategies and motivation that can affect students' outcomes in speaking English, that is, motivated learners have a greater desire to seek out solutions or support from others and employ more strategies to process the new information (Mandasari and Oktaviani, 2018). The external factors consist of subject matter factors and methods or learning models. 
Moreover, practicing speaking in the classroom takes time and students have less participation in speaking class (Mandasari and Aminatun, 2019).

In the current 2013 Curriculum, one of the speaking activities which is required in the Indonesian junior high school learning competency standard is storytelling skill. Through story competency standards, eighth-grade junior high school students are required to be able to master the basic competencies of telling the most memorable experiences, telling stories with visual aids, and telling stories in good order, pronunciation, intonation, gesture, and the right expression. Storytelling skill is important to master because it is useful for descriptive thinking and the ability to interact socially (Wahyudin, 2020). Sanjani (2015) explains that storytelling is the creation of a transactional relationship between reality, memory, and imaginary/narrative worlds. Transactional connections help students to what they know to contextualize what is unknown, thus affording the learner, in this case, the story listener, with the power to control understanding and knowledge. This shows how great the power of storytelling skills in helping students' thinking power. Through lecture and demonstration or the teacher gives examples of storytelling she has shown an effort to convey more varied storytelling learning. But it has not helped many students to overcome the obstacles that are faced when telling stories, such as fear, nervousness, and shame.

The use of Think Pair Share technique in storytelling learning will increase students' interest and enthusiasm in speaking activities by collaborating with friends. The method of learning to tell stories used is a paired storytelling technique. Paired Storytelling is developed as an interactive approach between students, instructors, and subject matter (Lie, 2004). Within pairs, students can vary in overcoming difficulties in telling stories in front of the class. At the sharing stage, students get the opportunity to show participation to others. Think-Pair-Share as one type of cooperative learning allows students to think, pair up or work with partners, share, and help one another, so it can add variety to learning models that are more interesting and enjoyable. It also can increase activity and student cooperation. This type of learning places students as subjects of learning.

The advantage of the Think-Pair-Share technique is the optimization of student participation. Compared to the conventional method that allows only one student to progress and share the results for the whole class, this type of Think-Pair-Share gives more opportunity for students to be recognized and show their participation to others (Lie, 2004). Think-Pair-Share technique is one of the simple cooperative learning models that has explicitly stated procedures so that it is easy to implement. Based on several studies, the use of Think-Pair-Share technique can help students overcome the obstacles of storytelling. Especially the use of paired storytelling techniques reduces individual student tension in storytelling.

According to Kagan (1994), the benefits of Think-Pair-Share technique are students use more time to do their work and listen to each other when they are involved in Think-Pair-Share activities and more students raise their hands to answer after practicing with their partner and teachers might also have more time to think when using Think-Pair-Share. They can concentrate on listening to students' answers, observe students' reactions, and ask high-level questions. Meanwhile, Lie (2005) argues that the strengths of paired groups are increasing student participation in the learning process, this technique is suitable for simple assignments, each student has more opportunities to contribute to his group, interaction in the group is easy to do, and group formation becomes faster and easier. In line with this argument, based on research conducted by Subrata (2009), concluded that by using a cooperative learning model of storytelling in pairs, students can be more active in developing thinking and imagination abilities. Therefore, Think-Pair-Share technique is one of the simple cooperative learning models that allow each student to carry out a process of "thinking-partner-sharing" activities in learning.

The steps in Think-Pair-Share technique are quite simple. This technique encourages teachers to ask students to think about a topic, pair up with other students and discuss it, then share it with the whole class. According to Lyman (1981), the first stage of Think-Pair-Share technique is thinking. The teacher provokes students' thinking with a question or prompt or observation. The second stage is the pairing. Using designated partners or a deskmate, students pair up to talk about the answer each came up with. The last stage is sharing. After students talk in pairs for a few moments, the teacher calls for pairs to share their thinking with the rest of the class. Kagan (1994) describes the stages of Think-Pair-Share technique involve a three-step cooperative structure. During the first step, individuals think silently about a question posed by the instructor. Individuals pair up during the second step and exchange thoughts. In the third step, share the responses with other pairs, other teams, or the entire group.

Think Pair Share technique with experimental methods can improve student learning outcomes and activities (Gani, Fajrina and Hanifa, 2015). Another study showed that $83 \%$ of students shared activities with other students and students reported that they were very involved with $62 \%$ during the thinking phase and $70 \%$ during the pairing phase (Khotiyal, 2013). It means that this method makes the students work in a group they can activate their prior knowledge of a topic at the beginning and share their idea with a group. In line with the description above, it can be stated that this study aimed to describe the implementation of Think-Pair-Share technique in teaching and learning storytelling as one of the productive skills in language and engaging student activities in the classroom. 


\section{LITERATURE REVIEW \\ The nature of the cooperative learning model}

Cooperative learning is a form of learning that is based on constructivist understanding. Cooperative learning is a learning strategy with several students as members of small groups with different levels of ability. In completing their group assignments, each student group member must work together and help each other to understand the subject matter. In cooperative learning, learning is said to be incomplete if one of the friends in the group has not mastered the lesson material.

The cooperative learning model is one of the learning models that support contextual learning. The cooperative learning teaching system can be defined as a working system / structured group learning. Included in this structure are the five main elements put forward by Johnson and Johnson namely positive interdependence, individual responsibility, personal interaction, collaboration skills, and group processes. Whereas Lie (2005) mentions the cooperative learning model is not the same as merely group learning, but there are basic elements that distinguish it from the division of groups which is done carelessly. This learning model places students as learning subjects (student-centered). With a democratic classroom atmosphere, mutual learning gives opportunities for greater opportunities to empower students to their full potential. The role of the teacher in cooperative learning as a facilitator, moderator, organizer, and mediator is visible.

\section{The nature of Think-Pair-Share}

Think-Pair-Share is one of the cooperative learning strategies that promotes and supports higher-order thinking (Macpherson, 2007). The teacher instructs students to think about a particular topic, in pairs with other students to discuss their ideas and share them with the group. This Think Pair Share strategy makes all students involved in-class activities such as discussions and provides opportunities for each student to share answers to each question. This learning method requires processing time and increases the depth of thought. Increased selfconfidence is one of the benefits of Think-Pair-Share. Many students feel more confident when they discuss their assignments with friends or discuss in pairs before they have to talk in a larger group in front of the class. Thinking becomes more focused when discussed with a partner. The second is the timer user allows all students to discuss their ideas. In the construction phase of this knowledge, students will find out what they know and don't know. Therefore, students are actively engaged in thinking. From that opportunity, students will be more critical in thinking to discuss and reflect on the topic. Students have the opportunity to share their thoughts with at least one other student, thereby increasing their sense of involvement.

Based on the statement above, it can be concluded that Think-Pair-Share has many benefits. Not only for students but has Think-Pair-Share also had benefits for the teacher. By using Think-Pair-Share, the teacher can create a situation to make the students active in the learning process. Moreover, the classroom is not a silent class anymore and students become active. The other benefit for students is the student confidence is increased and all students are given away to participate in class rather than some who usually volunteer. Students are actively engaged in thinking. More critical thinking is maintained after the lesson if students have the opportunity to discuss and reflect on the topic.

The use of this strategy will help students to draw on background knowledge to understand ideas, give students time to think, generate and analyze ideas, maintain a high level of engagement, participate in small group interactions. The use of this strategy also helps teachers increase their waiting time, thereby increasing students' thinking time, too. Waiting/thinking time has proven to be a strong factor in increasing students' responses to questions and questions. It takes time and it's hard to help all the trainers during discussions because they have so many groups are the disadvantages from polling stations. However, there are some advantages to TPS. According to Lyman (1981), Think-Pair-Share as one model of cooperative language learning has several advantages. They are as follows:

a. The Think-Pair-Share technique is fast and doesn't take much preparation time.

b. The Think-Pair-Share technique makes the class discussion more productive because students have had the opportunity to think about their ideas before sharing with the whole class.

c. Students have the opportunity to learn higher-order thinking skills from their peers and gain confidence when reporting ideas to the whole class.

d. The 'pairing' step ensures that no students are left behind from the discussion.

e. Students can practice responses mentally and verbally, and all students have the opportunity to speak.

f. Both students and teachers have increased opportunities to think and engage in group discussions.

g. Think-Pair-Share techniques apply at all levels and sizes of classes.

There are several previous reports have reported the potential of applying Think Pair Share in classroom learning. Some previous studies inform the implementation of Think Pair Share can improve students' understanding of learning material (Hermiati, 2017), creative thinking skills (Utami, 2014), as well as having an 
impact on student participation (Zainollah, 2014) and student motivation (Januartini et al., 2016)) during the learning process.

\section{METHOD}

\section{Method and type of research}

This research was conducted at one of Junior High Schools in Bandar Lampung. The treatment was carried out for 2 times face to face. This research method is a qualitative type of embedded single case study. Data sources include (1) informants, namely teachers and students, (2) Documents, namely storytelling skills learning plans using Think-Pair-Share type Cooperative Learning methods compiled by the teacher.

\section{Data Collection and Analysis}

Data collection techniques in this study were interview techniques, observation, and document analysis. Interview techniques were applied to informants which included teachers and students. The technique aimed to get information about the learning system that was applied and appreciation from the users of the learning methods applied. Observations carried out during the learning process took place to find out real events or facts that occurred in learning to tell stories. Document analysis was carried out on various documents supporting the learning process of storytelling, namely a lesson plan prepared by the teacher and the curriculum used by the teacher. The data that has been collected then was analyzed using interactive analysis techniques and presented in a descriptive form.

\section{FINDINGS AND DISCUSSION}

Based on the results of observations of learning in the field and analysis of the learning process plan documents, the implementation of Think-Pair-Share strategy in storytelling learning at one of Junior High Schools in Bandar Lampung implemented in eighth grade ran well and interactively. Learning indicators developed include (1) Being able to determine the main points of the story, (2) Being able to arrange the main points of the story into an interesting story sequence, and (3) Being able to tell stories using props based on the main points of the story. The materials presented in learning were how to tell a story, determine the main points of the story, various props supporting the success of telling a story, and how to deliver a story. The implementation of learning storytelling with the Think-Pair-Share strategy in the learning plan created by the teacher was applied in two meetings. Each meeting took 40 minutes. The objectives achieved in the first meeting were (1) students could determine the main points of the story, (2) students could arrange the main points of the story into an interesting story sequence. Learning objectives to be achieved at the second meeting was that students could tell stories with props by using an effective choice of words and sentences.

Each meeting specifically used three stages. The first stage is thinking. The teacher asked questions or issues related to storytelling skills, students were asked to think about these questions or issues independently for a few moments. Then, students answered questions on the answer sheet "Think" individually. They would start to think and read aloud the story text interactively in pairs to comprehend the meaning and content of the story. As a result of using interactive read aloud, where one student posed questions about a text as they read to help another student construct meaning and better understand the text. Barrentine (1996) suggested that these conversations help students become aware of key elements in the story that they might otherwise miss. The interactive component also allowed students to hear the perspectives of their peers which allows other students to become actively involved in the learning and provided a purpose for the learning process (Ayu, Diem, and Vianty, 2017). After comprehending the topic given by the teacher, the students were given a project to perform storytelling with their pair. They were required to understand instruction, recognize relevant information in written text, writing script, or narratives to prepare for the presentation. These activities could contribute significant positive effects on students' L2 comprehension and fluency (Wahyudin, 2017).

The second stage is the pairing. Students form groups in pairs then received the "Pair" answer sheet. The teacher asked students to pair up with other students to discuss what they have thought in the first stage. Students paired up to find agreement on the theme of the story and the techniques that would be used in storytelling. Students identified the stories that were known together in pairs and wrote them on the "Pair" answer sheet. Students determined the main points of the story based on the storyline and then arranged them into stories. They also determined the supporting props to tell the story following the selected story. After that, they practiced storytelling in pairs and reminded one another of mistakes and shortcomings, then for 5-10 minutes, students told a story that has been chosen in the previous meeting in pairs by using props in pairs in front of the class. Another pair of groups watched the weaknesses and strengths of their performance. This interactive activity can motivate and engage students with learning activities and create their interest in learning English in overcrowded classrooms (Ayu, 2018). Promoting interactive activities such as forcing students' engagement in pairs, group discussions and presentations can be alternative ways to aid students to learn English in a meaningful way and make them communicate effectively in English during the teaching and learning process. 
The last stage is sharing. In the final stage, the teacher asked the pair to share with the whole class what they have talked about. Students discussed the weaknesses and strengths of the work of each group in pairs. They discussed ways out of difficulty in determining the main points of the story and how to arrange them into stories. Devi, Musthafa, and Gustine (2015) mentioned that the discussion after storytelling is very important because sometimes there are students who have difficulties in grasping the meaning of the story in English. Sharing skills in the whole class can be done by appointing partners who were willing to volunteer to report the observations and experiences of the group or take turns pair by pair until about a quarter of the pair has had the opportunity to report. In this sharing stage, identifying the characteristics of classroom interaction is beneficial to the teachers in managing their classroom activities. The teachers are required to be a skillful manipulator using questions, commands, and other cues to elicit correct sentences from the students (Rido and Sari, 2018).

The application of storytelling learning with Think-Pair-Share strategy in the lesson plan specifically made by the teacher used stages that were following the general stages of the learning strategy. In other words, it does not come out of the main groove theoretically stages. The steps in learning Think-Pair-Share in general according to Lie (2004) are: (1) the teacher divides students into groups of four and gives assignments to all groups, (2) each student thinks and does the task himself, (3) students pair up with one of the colleagues in the group and discuss with their partners, (4) the two partners meet again in a group of four. Students have the opportunity to share their work with four groups (Lie, 2004). Stages of learning scenarios that have been stated in the learning process plan made have been implemented coherently by the teacher during the learning process of storytelling, although it does not rule out the teacher also improvises according to the learning situations and conditions.

In the learning process of storytelling in the second meeting, the second stage (Pair), the teacher applied a different paired group form to the first meeting. The paired storytelling technique used is paired storytelling. Paired Storytelling is developed as an interactive approach between students, instructors, and subject matter (Lie, 2004). The implementation of storytelling learning activities teachers has implemented the principles of learning following the curriculum used, namely using creative and interactive learning scenarios and integrating several aspects of language skills. Students not only improve speaking skills but also other receptive and productive skills because all language skills are interrelated related to unity.

As a result, appreciation for the implementation of Think-Pair-Share strategy was pretty good. The appreciation was conveyed by the users of the method namely the teacher and students as the recipient of the method. Both of them stated that the Cooperative Learning method of Think-Pair-Share type contributed to the learning of language skills, especially in storytelling skills. The method was sufficient to contribute to the learning process, both teachers and students, especially for improving student competency. Teachers as using this method are helped in various ways, including ease in planning and applying methods. In terms of planning, learning does not complicate teachers, especially in the preparation of materials, the selection of instructional media, preparation of scenarios learning, and assessment instruments. In terms of the implementation or application of the teacher's method, the benefits included finding an easy way to make the class conducive. Students could feel more enthusiastic and active during the learning process, easily in assessment, assisted in delivering material, and support other learning aspects (Zaim and Radjab, 2004).

Activities during the learning process using Think-Pair-Share strategy contributed to improving students' affective abilities, such as work cooperatively with fellow students and teachers, respecting differences of opinion, and other people's opportunities for opinion. Besides, with the Share stage, students were taught to manage emotions when speaking in public. Students as the recipient of the strategy stated that the Think-Pair-Share was able to overcome the obstacles in the process of storytelling learning, especially the "Pair" stage that promoted mutually supportive or cooperative cooperation between individuals. Working in pairs was very helpful in overcoming various problems of storytelling, including individual student tensions in storytelling, afraid of making mistakes, and nervous. In other words, they gained confidence in storytelling activities because the burden of students was reduced by collaboration with their partners or groups (Kusrini, 2012). The situation of interrupted or silence was almost non-existent because when students told stories in pairs, they complimented each other in silence. Besides, students helped their pairs in expressing imagination. Through the "Share" stage students also found it was helpful to break the deadlock because they could share with friends in various ways during the learning process. This stage was also able to develop an attitude of tolerance towards others, especially in managing emotions in public speaking, respecting differences of opinion, and respecting other people who were. Thus, Think-Pair-Share strategy in storytelling learning was also able to improve competencies in an integrated manner, both cognitive, psychomotor, and affective or attitude competencies together.

\section{CONCLUSION}

Based on the results of the analysis that has been described in the discussion, the conclusion in this study was Think-Pair-Share strategy has been implemented in one of Junior High School in Bandar Lampung. The implementation of learning storytelling with the Think-Pair-Share strategy in the learning plan specifically created by the teacher used stages that are appropriate to the general stages of the method and the implementation during the learning process of storytelling took place following the stages of the learning scenario that has been stated in 
the learning process plan made by the teacher. Appreciation for the implementation of Think-Pair-Share strategy both from the teacher and students as the recipient of the strategy is quite good. Students as recipients of the strategy stated that they were able to overcome the constraints in the learning process of storytelling more easily.

\section{REFERENCES}

Ayu, M. (2018). Interactive activities for effective learning in the overcrowded classroom. Linguists, 4(2), 1-6.

Ayu, M., Diem, C. D., \& Vianty, M. (2017). Secondary school students' English literacy: Use of interactive read aloud instructional strategy. International Journal of Applied Linguistics \& English Literature, 6(7), 292-299

Barrentine, S. J. (1996). Engaging with reading through interactive read-aloud. The Reading Teacher, 50(1), 36-43

Devi, A. P., Musthafa, B., \& Gustine, G. G. (2015). Using Cooperative Learning In Teaching Critical Thinking in Reading. English Review: Journal of English Education, 4(1), 1-14.

Gani, S. A., Fajrina, D., \& Hanifa, R. (2015). Students' Learning Strategies for Developing Speaking Ability. SIELE Journal, 2(1), 17-29.

Hermiati. (2017). the effectiveness of think-pair-share in teaching students' listening comprehension at the second grade in SMA Negeri 3 Sidrap. Alaudin State Islamic University Of Makasar. Retrieved from https://retosipori.uin alauddin.ac.id/7462/1/HERMIATIS.pdf

Januartini, P. D., Agustini, K., \& Sindu, I. G. P. (2016). Studi komparatif model pembelajaran think pair square amd think pair share terhadap motivasi dan hasil belajar siswa mapel TIK kelas X SMA N 1 Sukasada. Jurnal Pendidikan Teknologi dan Kejuruan, 13(2), 148-160.

Kagan, S. (1994). Cooperative Learning. San Clemente: Kagan Publications.

Kothiyal, A., Majumdar, M., Murthy, S., \& Iyer, S. (2013). Proceedings of the ninth annual international ACM conference on International computing education research. Effect of Think-Pair-Share in a Large CS1 Class: 83\% Sustained Engagement. San Diego: ACM.

Kusrini, E. (2012). Teaching speaking for senior high school students using cooperative learning "think pair share". Jurnal Aktif, 18(3), 1-8.

Kuswoyo, H. and Wahyudin, A. Y. (2017). Improving Student's Listening Skill Using Task-Based Approach in EFL Classroom Setting. Paper presented on 4th Asia Pacific Education Conference (AECON 2017). Retrieved at https://www.atlantis-press.com/proceedings/aecon-17/25884229

Lie, A. (2004). Cooperative Learning Mempraktekkan di Ruang-Ruang Kelas. Jakarta : PT. Grasindo.

Lyman, F. (1981). The Responsive Classroom Discussion. College Park, MD: University of Maryland College of Education.

Macpherson, A. (2007). Cooperative Learning Group Activities for College Courses- A Guide for Instructor. Surrey: Kwantlen University College.

Mandasari, B., \& Aminatun, D. (2019). Uncovering students' attitude toward vlogging activities in improving students' speaking ability. Premise Journal, 8(2), 214-225.

Mandasari, B., \& Oktaviani, L. (2018). English language learning strategies: an exploratory study of management and engineering students. Premise Journal, 7(2), 61-79.

Nunan, D (Ed.). (2003). Practical English Language Teaching. New York: McGraw-Hill.

Raba, A. A. A. (2017). The Influence of Think-Pair-Share (TPS) on Improving Students' Oral Communication Skills in EFL Classrooms. Creative Education, 8, 12-23.

Rido, A., \& Sari, F. M. (2018). Characteristics of classroom interaction of English language teachers in Indonesia and Malaysia. International Journal of Language Education, 2(1), 40-50

Sanjani, E. D. (2015). Improving students speaking ability using Think Pair Share of Cooperative Learning for the $8^{\text {th }}$ Grade Students of MTs N Karangmojo In the Academic Year of 2014/2015. Indonesia.

Sari, F. M. (2018). Patterns of teaching-Learning Interaction in the EFL Classroom. Teknosastik: Jurnal Bahasa dan Sastra, $16(2), 41-48$.

Subrata, H. (2009). Penerapan Pembelajaran Kooperatif Tipe Bercerita Berpasangan Pada Mata Pelajaran Bahasa Indonesia Di Kelas VI Sekolah Dasar. http://makalahkumakalahmu.wordpress.com/2009.

Utami, H. W. (2014). Effectivitas pembelajaran kooperatif model think-pair-share berbantuan video pembelajaran dalam meningkatkan kreativitas siswa pada kompetensi dasar laporan keuangan. Economic Education Analysis Journal, 2(3), $60-67$.

Wahyudin, A. Y. (2017). The effect of project-based learning on L2 spoken performance of undergraduate students in English for Business class. Advances in Social Science, Education, and Humanities Research (ASSEHR), 82, 42-46. Presented on The Ninth International Conference on Applied Linguistics (Conaplin 9).

Wahyudin, A. Y., Jepri, D., Simamora, M. W., Pratiwi, I. W., \& Rina, A. (2020). Penggunaan komik digital Toondoo dalam pembelajaran Bahasa Inggris tingkat sekolah menengah. Journal of Social Sciences and Technology for Community Service (JSSTCS) 1(1). 1-6

Zaim, R., \& Radjab, D. (2004). Improving Students' Speaking Skill by Using Think- Pair- Share Strategy at the Second Semester of Syariah Class at Language Center of UIN Suska Riau. Journal of English Language Teaching (ELT), 2(1), 1-12.

Zainollah. (2014). Increasing students' speaking ability and active participation in the classroom trough think-pair-square. Kariman, 2(2), 117-130. 


\section{BIOGRAPHY OF AUTHORS}

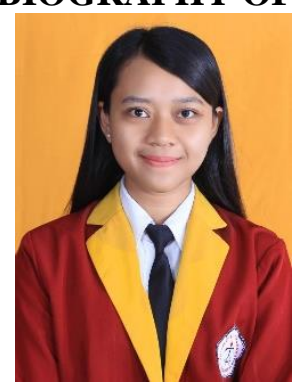

Dian Aprianti is a college student from the English Education study program, Faculty of Arts and Education, Universitas Teknokrat Indonesia.

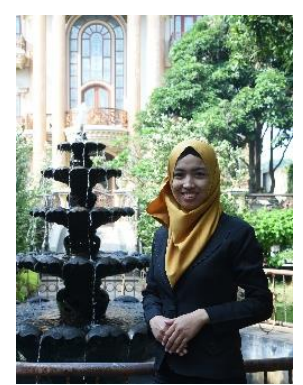

Mutiara Ayu is an English Education Lecturer in Universitas Teknokrat Indonesia. She actively participates as a presenter at national and international conferences and publishes her studies in journals. Her research interest is English teaching and learning, teaching strategies, textbook evaluation, and TEYL. 